\title{
DEVELOPMENT OF PUPIL'S SELFASSESSMENT AS A PART OF TEACHER'S ASSESSMENT STRATEGY IN TECHNICAL EDUCATION AT PRIMARY SCHOOL
}

Pavlína Č́STKOV $\boldsymbol{A}^{*}$, Univerzita Palackého v Olomouci, Česká republika

Přijato: 21. 7. 2018 / Akceptováno: 30. 10. 2018

Typ článku: Výzkumný článek

DOI: $10.5507 /$ jtie.2018.010

Abstract: The article presents self-assessment as an important part of the teacher's assessment of the pupil and at the same time as one of the key category influencing pupil formation in the first years of compulsory school attendance. The aim of the article is to present partial results of a case study focused on the reflection of the current state of teacher evaluation processes in the implementation of technical education at primary school. Evaluations in such specifically focused subjects as technically oriented subjects are significantly influenced by several factors - the most important is the teacher. The article presents answers to questions - how does a teacher engage a pupil in the assessment and induce self-evaluating pupil activities?

Key words: school assessment, teacher's assessment strategy, primary school, technical education, case study, research.

\section{ROZVOJ SEBEHODNOCENÍ ŽÁKA JAKO SOUČÁST HODNOTÍCÍ STRATEGIE UČITELE V TECHNICKÉ VÝCHOVĚ NA PRIMÁRNÍ ŠKOLE}

Abstrakt: Článek prezentuje sebehodnoceni jako významnou součást hodnocení žáka učitelem a současně jako jednu z klićových kategorii ovlivňujicí formování žáka v prvnich letech povinné školni docházky. Cílem článku je prezentovat dílči výsledky prípadové studie zaměrené na reflexi současného stavu hodnotícich procesů učitele prì realizaci technické výchovy na primární škole. Hodnocení $v$ tak specificky zaměrených predmětech, jako jsou technicky orientované předměty, je významně ovlivňováno několika faktory, z nichž nejvýznamnějši je faktor učitele. Článek předkládá odpovédi na otázky - jakým způsobem učitel zapojuje žáka do hodnoceni a navozuje sebehodnotící aktivity žáka?

Klíčová slova: školní hodnocení, hodnotící strategie učitele, sebehodnocení žáka, primární škola, technická výchova, prrípadová studie, výzkum.

*Autor pro korespondenci: pavlina.castkova@upol.cz 


\section{1 Úvod}

Období prvních let školní docházky představuje pro dítě velkou životní změnu. Dochází k proměně jeho role, musí se adaptovat do nového prostředí, navazuje vztahy s dospělými i vrstevníky, zásadně se mění denní program, činnosti i jejich obsah, rostou požadavky na způsoby jeho chování i jednání. Zatímco před nástupem do základní školy vnímá dítě hodnocení své osoby pouze velmi omezeně, v nové školní realitě je hodnocení součástí běžné každodenní pedagogické komunikace. (Slavík, 1999) Zde představuje hodnocení určité sdělení žákům o jejich snaze, úspěšnosti, chybách i postojích ve vztahu k učivu. M. Dvořáková (2007) definuje hodnocení jako vyjádření výsledků vyučování a učební činnosti žáka ve vztahu ke stanovenému cíli. Z psychologického hlediska pak představuje hodnocení určitou charakteristiku či klasifikaci jevů, která vždy obsahuje subjektivní vliv hodnotitele. (Hartl, Hartlová, 2004) J. Slavík (2009, s. 587) pojímá definici hodnocení žáků komplexněji jako ,interpretační a komunikační proces, který poskytuje diagnostické informace o porovnatelných kvalitách učebnich výkonů a chováni žáků s cilem zvyšovat kvalitu učeni a efektivitu vyučování. Hodnocení ovlivňuje autoregulaci žákovského učení a motivaci k němu, působí na sociální vztahy, sebepojetí nebo aspirace žákü“.

Školní hodnocení žáků je především proces, který má podporovat pedagogicky žádoucí aktivity a eliminovat ty nežádoucí. Je realizováno mnoha způsoby od učitelem určené pětistupňové klasifikace po samostatnou sebehodnotící aktivitu žáků. Je rovněž plně závislé na charakteru vyučování a typu školy, odráží se v něm povaha edukačních cílů i individuální př́stup učitele. Školní hodnocení může být realizováno prostřednictvím klasifikace nebo $\mathrm{v}$ případě slovního hodnocení písemných zpráv, popř. hodnocení vzdělávacích výsledků žáků prostřednictvím testování, at' už na státní či mezinárodní úrovni. ${ }^{1}$ (Průcha, Walterová, Mareš, 2009) Obecný význam hodnocení v pedagogice spočívá ve zjišt’ování, porovnávání a vysvětlování dat, která charakterizují stav, kvalitu a fungování vzdělávacího systému a jeho dílčích částí. To vše za účelem korekce, inovace a rozvoje edukační reality i celého systému. V souvislosti s uvedeným chápou někteří autoři hodnocení jako synonymum k pedagogické evaluaci. (Pasch, 1998)

Ve školství je však problematické, ne-li nemožné jednoznačně posoudit žákův výkon, přestože je formulován v podobě edukačních cílů. K tomu, aby byla výsledná „známka“ validní a reliabilní, by muselo být přesně stanoveno co hodnotit (vědomosti, dovednosti, návyky, postoje), kdy hodnotit (resp. jak často) a musela by být přesně vymezena „hodnota“ jednotlivých klasifikačních stupňů tak, aby byla známka shodná i v případě hodnocení více učiteli. (Turek, 1987)

Podmínky a pravidla hodnocení žáků jsou zakotvena $\mathrm{v}$ Rámcovém vzdělávacím programu pro základni vzdělávání (dále jen RVP ZV). Ten udává, že pro hodnocení výsledků vzdělávání žáků se řídí § 51 až § 53 školského zákona. Podrobnosti ohodnocení výsledků žáků a jeho náležitostech je stanoveno v § 14 vyhlášky č. 48/2005 Sb., novelizována vyhláškou 256/2012 Sb. a vyhláška č. 147/2011 Sb., o vzdělávání dětí, žáků a studentů se speciálními vzdělávacími potřebami a dětí, žáků a studentů mimořádně nadaných. Zde je deklarováno, že každá škola je povinná zařadit do školního řádu pravidla pro hodnocení a sebehodnocení žáků výsledků vzdělávání žáků i kritéria pro hodnocení (§ 14). Dále jsou stanoveny klasifikační stupně při využití známkování a rovněž pravidla

\footnotetext{
${ }^{1}$ Např. PISA, TIMSS, PIRLS, ICILS, TALIS, státní testování v 5. a 9. ročníku.
} 
pro slovní hodnocení (§ 15) a závěrečné hodnocení, včetně nehodnocení žáka z určitého předmětu (§ 16).

$\mathrm{Na}$ základě legislativních dokumentů a RVP ZV si každá škola vytváří vlastní hodnotící předpisy - klasifikační řád, který je nejčastěji součástí školního vzdělávacího programu $^{2}$. Tato pravidla si škola formuluje v souladu se specifickou filosofíi, do které je možné zahrnout zvolenou vzdělávací koncepci; hodnoty, které škola prosazuje a rozvijí; výchovné a vzdělávací cíle; obsah vyučování; emoční a sociální klima školy; odborně-personální a osobnostní specifika pedagogických pracovníků; uplatňované organizační formy vyučování; výchovné a vzdělávací metody; metody a formy hodnocení; prezentované výstupy školy a v neposlední řadě také profil absolventa konkrétní školy.

\section{Hodnotící strategie učitele při realizaci technické výchovy}

Školní vzdělávací program každé školy sice deklaruje základní charakteristiky hodnocení, které si volí každá škola a učitel by je měl plně respektovat, přesto se v edukačním procesu uplatňuje i v této oblasti značná míra učitelova osobnostního pojetí. Plánování a realizace nejvhodnější cesty hodnocení žáka se tedy mohou různit u každého učitele i v každé třídě.

Hodnocení v předmětech s převahou výchovného působení ${ }^{3}$ je složité zejména proto, že každý učitel může přistupovat $k$ technické výchově odlišně. Někteří zdůrazňují její relaxační funkci a považují tradiční hodnocení formou klasifikace za limitující či zbytečné. Další skupina učitelů vnímá technickou výchovu jako předmět, který má především formovat postoje žáka, což není možné ani účelné klasifikovat. Snahou učitelů by mělo být nalezení nejobjektivnějšího přístupu $\mathrm{k}$ hodnocení, který především poskytne žákovi adekvátní zpětnou vazbu a umožní mu nadále se rozvíjet. Podrobněji o specificích hodnocení v technické výchově např. Částková, Stolinská (2017); Částková (2017) aj.

Mezi hodnotící strategie učitele př̌i realizaci technické výchovy můžeme zařadit např.:

a) hodnocení podle kritérí,

b) hodnocení kompetencí,

c) rozvoj sebehodnocení žáka,

d) výhradně pozitivní hodnocení (motivační),

e) kombinace výše uvedených,

f) absence hodnocení.

Každou z uvedených strategií je možné analyzovat z různých pohledů, v článku se však blíže věnujeme pouze sebehodnocení žáka. Cílem nácviku sebehodnocení žáka je osvojení dovednosti samostatně kriticky posoudit př́pravu, průběh i výsledek vlastní činnosti z hlediska zpětného pohledu na své výkony. Žák schopný sebehodnotit (se) by si měl osvojit hodnocení na prvních dvou úrovních Bloomovy taxonomie, tedy zapamatovat a porozumět. (Skalková, 2007) Tedy nejprve rozpoznat dílčí prvky vlastní práce, které poukazují na dosažení stanoveného cíle (naplnění kritérií) a následně popsat a vysvětlit důvody svého tvrzení. Dále také identifikovat silné stránky i limity a naplánovat svou další činnost tak, aby eliminoval možný neúspěch. Všechny tyto činnosti musí učitel nejprve opakovaně absolvovat společně s žákem. Teprve tehdy, stane-li se proces sebehodnocení

\footnotetext{
2 Pravidla pro hodnocení je možné mít i jako samostatný dokument.

${ }^{3} \mathrm{~V}$ pravidlech a podmínkách hodnocení v některých ŠVP je možné naleznout označení technické výchovy také jako předmětu s převahou praktického zaměření nebo praktických činností.
} 
přirozenou součástí výuky, budou žáci schopni prristupovat otevřeně k vlastním chybám i úspěchům. (Koštálová, Miková, Stang, 2009) Kvalitní osvojení sebehodnotící dovednosti předpokládá především zajištění dobrých podmínek učitelem. Mezi klíčové podmínky je možné zařadit např. vhodné klima tř́dy, partnerský vztah mezi učitelem a žáky, žákův pocit bezpečí a sounáležitosti, ale také dostatek času na sebehodnotící aktivity a uplatnění kvalitních sebehodnotících nástrojů. (Kratochvílová, 2011)

Činnosti s technikou jako nedílná součást lidského života dospělých i dětí poskytují ideální podmínky k rozvoji sebehodnocení žáka. Svým praktickým zaměřením umožňují žákům získat nezbytné znalosti, pracovní dovednosti i návyky nutné pro další vzdělávání, profesní orientaci i každodenní život.

\section{Výzkumné šetření a jeho metodika}

V následující kapitole prezentujeme dílčí výsledky výzkumného šetření, které bylo realizováno v rámci zpracování rigorózní práce s názvem Rozvoj sebehodnoceni żáka $v$ technické výchově na primární škole. Předmětem výzkumu byla problematika rozvoje sebehodnocení žáka ve výuce technické výchovy v prvním ročníku základní školy. Mezi sledované jevy patřily hodnotící činnosti učitele, hodnotící činnosti žáka a s ní spojená vzájemná komunikace a interakce mezi účastníky edukačního procesu. K realizaci výzkumného šetření byla zvolena strategie smíšeného designu s využitím metody př́padové studie. Metoda byla vybrána $\mathrm{z}$ důvodu snahy zachycení komplexity složitosti príípadu $\mathrm{v}$ jeho přirozeném prostředí a porozumění procesu rozvoje sebehodnocení žáka jako sociálnímu objektu $\mathrm{v}$ jeho jedinečnosti. Konkrétně byla použita intrinsitní př́padová studie podle R. Stake (1995), která se vyznačuje detailním studiem vnitřních aspektů určitého př́padu. (Hendl, 2005) Cílem realizovaného výzkumu bylo hledat odpovědi na výzkumné otázky:

-Jakým způsobem učitel zapojuje žáka do hodnocení?

-Jakým způsobem učitel navozuje sebehodnotící aktivity žáka?

Realizovaná př́padová studie měla následující fáze (Švaříček, Šed’ová et al., 2007):

1. určení výzkumného tématu a definování základních výzkumných otázek,

2. výběr zkoumaného případu a definování etických kritérií,

3. sběr dat,

4. analýza a interpretace dat.

Jako metody sběru dat byly zvoleny obsahová analýza dokumentů, nezúčastněné strukturované pozorování a polostrukturovaný rozhovor s otevřenými otázkami. Cílem článku je prezentovat dílčí výsledky studie - nezúčastněného strukturovaného pozorování.

\subsection{Popis výzkumného nástroje}

Jako jedna z výzkumných metod byla zvolena interakční mikroanalýza, která identifikuje verbální projevy $\mathrm{v}$ interakci učitel-žák. Původním záměrem bylo aplikovat Bellackovu interakční analýzu (Bellack, 1966), nicméně pro potřeby identifikace a kategorizace specifických hodnotících výrokủ bylo vytvořeno jedinečné kódování vycházející z principů Bellackovy a Flandersovy metody interakční analýzy (Flanders, 1970; Svatoš, 1995). V rámci výzkumu bylo aplikováno otevřené kódování (Strauss, Corbinová, 1999), které umožní zaznamenat jednotlivé hodnotící situace ve výuce i dílčí hodnotící výroky. Pro záznam hodnotících aktivit v interakci učitel - žák bylo vytvořeno 
celkem dvanáct kategorií komplexně mapujících hodnotící činnost učitele i žáka. Celkem devět kategorií je společných pro učitele i žáka, zbylé tři se liší.

$\mathrm{V}$ případě, kdy je mluvčím učitel je každá pedagogická akce kódována následovně: hodnoceni z hlediska procesu učení, hodnoceni z hlediska způsobu komunikace, hodnocení z hlediska citového zabarveni výroku, hodnoceni z hlediska zpětné vazby, hodnoceni z hlediska vztahové normy, hodnoceni z hlediska obsahu hodnoceni, hodnocení z hlediska objektu hodnoceni, hodnocení z hlediska užití jazyka, hodnocení z hlediska prripravenosti, dotazováni nebo výzva žáka za účelem hodnoceni. Součástí kódování je i kategorie ostatní, kterou tvoří např. seznámeni žáků s edukačním cílem hodiny a seznámeni žáků s hodnotícimi kritérii. Pokud je mluvčím žák, posloupnost prvních devíti kategorií je shodná jako u učitele, poslední tři kategorie, se člení následovně: hodnocení z hlediska participace žáků, hodnocení z hlediska aktivity žáka a kategorie ostatní, kam je možné zařadit nestandardní situace hodnocení žákem. Uplatňovaná metoda analýzy vychází z mikroetnografické analýzy diskurzu, kde je vyučování chápáno jako sociálně-lingvistický proces. (Šed’ová, 2015)

\begin{tabular}{|c|c|c|}
\hline Kategorie & Typy hodnocení - učitel & Typy hodnocení - žák \\
\hline \multirow{2}{*}{$\begin{array}{l}\text { 1. Typ hodnocení } \\
\text { z hlediska procesu } \\
\text { učení }\end{array}$} & Formativní hodnocení & Formativní hodnocení \\
\hline & Sumativní hodnocení & Sumativní hodnocení \\
\hline \multirow{4}{*}{$\begin{array}{l}\text { 2. Typ hodnocení z } \\
\text { hlediska způsobu } \\
\text { komunikace }\end{array}$} & $\begin{array}{l}\text { Slovní hodnocení - stručné, } \\
\text { jednoslovné, citoslovce }\end{array}$ & $\begin{array}{l}\text { Slovní hodnocení - stručné, } \\
\text { jednoslovné, citoslovce }\end{array}$ \\
\hline & $\begin{array}{l}\text { Slovní hodnocení - } \\
\text { víceslovné zdůvodnění } \\
\text { hodnocení }\end{array}$ & $\begin{array}{l}\text { Slovní hodnocení - víceslovné } \\
\text { zdůvodnění hodnocení }\end{array}$ \\
\hline & Neverbální hodnocení & Neverbální hodnocení \\
\hline & Grafické hodnocení & Grafické hodnocení \\
\hline \multirow{3}{*}{$\begin{array}{l}\text { 3. Typ hodnocení } \\
\text { z hlediska citového } \\
\text { zabarvení výroku }\end{array}$} & Pozitivní hodnocení & Pozitivní hodnocení \\
\hline & Negativní hodnocení & Negativní hodnocení \\
\hline & Neutrální hodnocení & Neutrální hodnocení \\
\hline \multirow{3}{*}{$\begin{array}{l}\text { 4. Typ hodnocení } \\
\text { z hlediska zpětné } \\
\text { vazby }\end{array}$} & Hodnocení se zdůvodněním & Hodnocení se zdůvodněním \\
\hline & Hodnocení bez zdůvodnění & Hodnocení bez zdůvodnění \\
\hline & $\begin{array}{l}\text { Hodnocení s návrhy } \\
\text { k překonání nedostatků }\end{array}$ & $\begin{array}{l}\text { Hodnocení s návrhy k překonání } \\
\text { nedostatků }\end{array}$ \\
\hline \multirow{2}{*}{$\begin{array}{l}\text { 5. Typ hodnocení } \\
\text { z hlediska celistvosti }\end{array}$} & Hodnocení analytické & Hodnocení analytické \\
\hline & Hodnocení holistické & Hodnocení holistické \\
\hline \multirow{3}{*}{$\begin{array}{l}\text { 6. Typ hodnocení } \\
\text { z hlediska vztahové } \\
\text { normy }\end{array}$} & Normativní hodnocení & Normativní hodnocení \\
\hline & Kriteriální hodnocení & Kriteriální hodnocení \\
\hline & $\begin{array}{l}\text { Hodnocení podle } \\
\text { individuální vztahové normy }\end{array}$ & $\begin{array}{l}\text { Hodnocení podle individuální } \\
\text { vztahové normy }\end{array}$ \\
\hline \multirow{6}{*}{$\begin{array}{l}\text { 7. Typ hodnocení } \\
\text { z hlediska obsahu } \\
\text { hodnocení }\end{array}$} & Znalosti & Znalosti \\
\hline & Dovednosti & Dovednosti \\
\hline & Postoje, chování & Postoje, chování \\
\hline & $\begin{array}{l}\text { Schopnosti, vlohy, nadání, } \\
\text { vlastnost }\end{array}$ & $\begin{array}{l}\text { Schopnosti, vlohy, nadání, } \\
\text { vlastnost }\end{array}$ \\
\hline & Výsledek činnosti, výrobek & Výsledek činnosti, výrobek \\
\hline & Snaha, aktivita, výkonnost & Snaha, aktivita, výkonnost \\
\hline \multirow{3}{*}{$\begin{array}{l}\text { 8. Typ hodnocení } \\
\text { z hlediska objektu } \\
\text { hodnocení }\end{array}$} & Hodnocení žáka - dívka & Hodnotí sám sebe \\
\hline & Hodnocení žáka - chlapec & Hodnotí spolužáka - dívku \\
\hline & $\begin{array}{l}\text { Hodnocení skupiny } \\
\text { žáků/třídy }\end{array}$ & Hodnotí spolužáka - chlapce \\
\hline
\end{tabular}




\begin{tabular}{|c|c|c|}
\hline & $\begin{array}{l}\text { Hodnocení anonymní, } \\
\text { neurčité }\end{array}$ & Hodnotí práci skupiny \\
\hline & & Hodnocení anonymní \\
\hline & & Hodnocení učitele \\
\hline \multirow{2}{*}{$\begin{array}{l}\text { 9. Typ hodnocení } \\
\text { z hlediska užití } \\
\text { jazyka }\end{array}$} & Užívání posuzujícího jazyka & Uživání posuzujícího jazyka \\
\hline & Uživání popisného jazyka & Uživání popisného jazyka \\
\hline \multirow{4}{*}{$\begin{array}{l}\text { 10. Typ hodnocení } \\
\text { z hlediska } \\
\text { připravenosti }\end{array}$} & Bezděčné hodnocení & Samostatně - dívka \\
\hline & $\begin{array}{l}\text { Záměrné operativní } \\
\text { hodnocení }\end{array}$ & Samostatně - chlapec \\
\hline & $\begin{array}{l}\text { Záměrné formalizované } \\
\text { hodnocení }\end{array}$ & Hromadně \\
\hline & & Hodnocení anonymní \\
\hline \multirow{7}{*}{$\begin{array}{l}\text { 11. Dotazování nebo } \\
\text { výzva učitele za } \\
\text { účelem hodnocení }\end{array}$} & $\begin{array}{l}\text { Dotazování (nebo výzva) } \\
\text { žáků hromadně }\end{array}$ & Hodnotí na základě otázky učitele \\
\hline & $\begin{array}{l}\text { Dotazování (nebo výzva) } \\
\text { konkrétního žáka }\end{array}$ & Hodnotí bez vyzvání učitele \\
\hline & $\begin{array}{l}\text { Otázka s uzavřenou } \\
\text { odpovědí }\end{array}$ & \\
\hline & $\begin{array}{l}\text { Otázka s otevřenou } \\
\text { odpovědí }\end{array}$ & \\
\hline & Pozitivní dotazování & \\
\hline & Negativní dotazování & \\
\hline & Neutrální dotazování & \\
\hline \multirow[t]{2}{*}{ 12. Ostatní } & $\begin{array}{l}\text { Seznámení žáků } \\
\text { s edukačním cílem hodiny }\end{array}$ & \\
\hline & $\begin{array}{l}\text { Seznámení žáků } \\
\text { s hodnotícími kritérii }\end{array}$ & \\
\hline
\end{tabular}

\section{Tab. č. 1: Kategorie interakční analýzy hodnotících situací}

Z hlediska procesu učení jsme $\mathrm{v}$ souladu s teoretickými východisky vyčlenili typy hodnocení na formativní a sumativní. Do sumativního hodnocení jsme zařadili hodnotící výroky nezávisle na části hodiny, ve které byly zaznamenány. Jako sumativní jsme označili takové výroky, jejichž sdělení již bezprostředně neovlivnilo průběh a výsledek činnosti žáka. Ten naopak ovlivňovalo formativní hodnocení učitelky.

Mezi typy hodnocení $\mathrm{z}$ hlediska komunikace jsme zařadili celkem čtyři kategorie, a to hodnocení slovní - to jsme dále členili na hodnocení stručné, jednoslovné nebo citoslovce, dále hodnocení slovní víceslovné, které většinou obsahovalo i zdůvodnění hodnocení. Dalším typem bylo neverbální hodnocení, to však z důvodu pořízení audionahrávek nebylo možné identifikovat. Jediný neverbální hodnotící projev, který jsme v rámci výzkumu zaznamenali, byl potlesk žáků. Posledním typem hodnocení z hlediska komunikace je grafické hodnocení prostřednictvím obrázků, symbolů aj.

Hodnotící výroky byly dále členěny z hlediska citového zabarvení výroku, do této kategorie jsme řadili hodnocení pozitivní, negativní a neutrální.

Čtvrtou kategorií je hodnocení z hlediska zpětné vazby, kam jsme zařadili hodnocení bez zdůvodnění, hodnocení se zdůvodněním a hodnocení s návrhy k překonání nedostatků.

Následovala kategorie hodnocení z hlediska celistvosti, které členíme na analytické a holistické hodnocení.

Z hlediska obsahu hodnocení rozlišujeme tradiční hodnocení znalostí, dovedností, postojů a chování doplněné o kategorie výsledek činnosti žáka a snaha a aktivita žáka. 
Poslední dvě kategorie nabývají na významu zejména v kontextu předmětu Pracovní činnosti, v rámci kterého byl výzkum realizován.

Z hlediska objektu hodnocení jsme vyčlenili hodnocení žáka - dívky, hodnocení žáka - chlapce, hodnocení skupiny žáků a hodnocení anonymní. Jako anonymního hodnocení jsme označili takový hodnotící výrok, u kterého nebylo možné z pohledu výzkumníka identifikovat adresáta nebo adresát úmyslně nebyl znám ani žákům. Při žákovském hodnocení byla tato kategorie rozšiřrena o položky sebehodnocení žáka a hodnocení učitele.

Z hlediska užití jazyka jsme dělili hodnotící výroky, ve kterých bylo užíváno posuzujícího jazyka a hodnoticí výroky, ve kterých bylo užíváno popisného jazyka. (Viz např. Koláŕ, Šikulová, 2009; Čapek, 2015; Honzíková, 2016 aj.)

Desátá kategorie byla první, která se lišila pro učitele a pro žáka. Při analýze hodnotících výroků učitele jsme $\mathrm{v}$ rámci kategorie rozlišovali typy hodnocení $\mathrm{z}$ hlediska připravenosti na hodnocení bezděčné, hodnocení záměrné operativní a hodnocení záměrné formalizované (finální). $V$ případě analýzy hodnocení žáků jsme vytvořili typologii hodnocení z hlediska participace žáků. Zde jsme odlišovali hodnocení samostatné (různě dívka - chlapec) a hodnocení hromadné, kdy hodnotila celá tř́ída nebo skupina žáků současně.

Další kategorie hodnotících výroků učitele představovala dotazování nebo výzvy učitele $\mathrm{k}$ hodnocení. Tuto kategorii jsme šířeji rozpracovali a v průběhu analýzy doplňovali dle charakteru výroků učitelky.

Typy dotazování nebo výzev jsme vyčlenili následovně: dotazování žáků hromadné, dotazování konkrétního žáka, otázka s uzavřenou odpovědí, otázka s otevřenou odpovědí, pozitivně laděné dotazování, negativně laděné dotazování, neutrálně laděné dotazování. U hodnotících výrokủ žáka jsme oblasti obsahově propojili a vytvořili kategorie hodnocení z hlediska aktivity žáka, a to na hodnocení na základě výzvy učitele a hodnocení bez vyzvání učitele.

Poslední položkou je jak u výroků žáka, tak u výroků učitele kategorie ostatní, kam u učitele spadá např. seznámení žáků s edukačním cílem hodiny nebo seznámení žáků s hodnotícími kritérii. U hodnotících výroků žáka v kategorii ostatní žádné konkrétní typy neuvádíme, přičemž předpokládáme, že tato položka poskytne prostor $\mathrm{k}$ zařazení nestandardních hodnotících výrokủ žáka.

\subsection{Charakteristika výzkumného vzorku}

Výzkum byl realizován v hodinách předmětu Praktické činnosti v 1. ročníku ve školním roce 2016/2017 na městské ZŠ. Základní škola je úplná škola s devíti postupnými ročníky a kapacitou 330 žáků. Ve sledovaném období tvořilo první ročník celkem 33 žáků z toho 20 dívek a 13 chlapců. Integrován byl jeden chlapec s vadou řeči. Podpůrné opatření 1. stupně měla jedna dívka, avšak podle vyjádření třídní učitelky jí běžné úkony v Pracovních činnostech nečinily žádné potíže. Celkem osm žáků je po odkladu povinné školní docházky, z toho 5 dívek a 3 chlapci. Všichni žáci ve třídě docházeli do mateřské školy.

Trrídní učitelka má vysokoškolské vzdělání, má 31 let praxe a vyučuje opakovaně 1. a 2. ročníky. Ve třídě vyučuje všechny předměty, celkem 20 hodin týdně. Ve škole působí jako vedoucí metodického sdružení pro první stupeň, mimo to spolupracuje s mateřskou školou, kde se věnuje se př́ípravě dětí předškolního věku na vstup do školy.

Výběr výzkumného vzorku se odvíjel jednak od záměru komplexně zmapovat stanovené jevy, hledat jejich prričiny a souvislosti a analyzovat je $v$ jejich vývojové podobě. 
Výběr unikátního př́ípadu s nadměrným počtem žáků4 ve třídě umožňuje nahlédnout a posoudit problematiku hodnocení žáků především z hlediska úrovně jeho kvality. Průběh a podmínky výzkumných procedur byly učitelce předem vysvětleny, přičemž byla seznámena s tématem výzkumu pouze rámcově, aby nedošlo k ovlivnění jejího chování a jednání ve výuce.

Činnosti realizované v rámci pozorovaných hodin byly zaměřeny na práci s drobným technickým materiálem. Témata a náměty hodin byly vybrány nezávisle na realizovaném výzkumu dle fenologického principu a přizpůsobeny aktuální situaci ve škole. Obsahem hodin byly aktivity zaměřené na osvojování pracovních kompetencí a rozvoj jemné motoriky žáků prostřednictvím jednoduchých činností, které jsou základem pro další technicky orientované aktivity žáků ve vyšších ročnících.

\section{Analýza hodnotících výroků žáků}

Vzhledem $\mathrm{k}$ tomu, že hlavním nositelem pedagogického dění v podobě hodnocení je učitelka, většina hodnotících výroků žáků vznikala jako reakce na dotazy učitelky. Proto i charakter žákovského hodnocení odpovídal stylizaci učitelčiných dotazů.

Z hlediska způsobu komunikace se žáci vyjadřovali jak verbálně, tak neverbálně. Neverbální hodnocení bylo ve sledovaných hodinách identifikováno výhradně 5 jako potlesk žáků na konci vyučovací hodiny. V žákovských hodnotících výrocích se velmi často objevovaly stručné nebo jednoslovné odpovědi na dotazy učitelky, kdy byli žáci vyzýváni $\mathrm{k}$ dokončování vět.

\section{Ukázka $1^{6}$ :}

U: Já, když jsem se divala na ty housenky, které vám ted’ laminuji, nebo budu laminovat, tak nékdo to má okousané jak od myši. To neni vủbec...

Ž: Hezké.

U: Janičko, poslouchášs? Takhle, někde je to těžši, a když nám ten papirek zavazí, co udělám?

D: Odstřihnu ho.

U: Odstřihnu ho, a kam uklizime papiry?

Ž: Do krabice.

U: Do krabice, já vám krabici nachystám. Tady je nachystaná krabice, takže ..., anebo je ještě dobré, že si takhle to odstřihnu to, co mi zavazí.

Ž-D: A nemusime tolik střihat.

U: Výborně. A takhle si pěkně budu postupovat a pozor, protože tady jsou prstíky, ona by začala bolestí mňoukat ta kočička, kdybychom ji ty prstíky....

Ž: Ustřihli.

U: Ustřihli, takže takhle budeme točit. Je to jasné?

Ž: Ano.

U: Děti, co zaprvé budeme dělat, než půjdeme do lavice?

Ž: Malovat.

Ž: Klubička.

U: Malovat, budeme dělat klubička. Co potom, až budeme mit klubićka?

\footnotetext{
${ }^{4}$ Škole byla udělena výjimka zřizovatelem dle zákona 561/2004 Sb.

${ }^{5}$ Vzhledem k tomu, že bylo realizováno nezúčastněné pozorování.

${ }^{6}$ Veškerá uvedená jména byla $\mathrm{z}$ důvodu anonymizace pozměněna.
} 


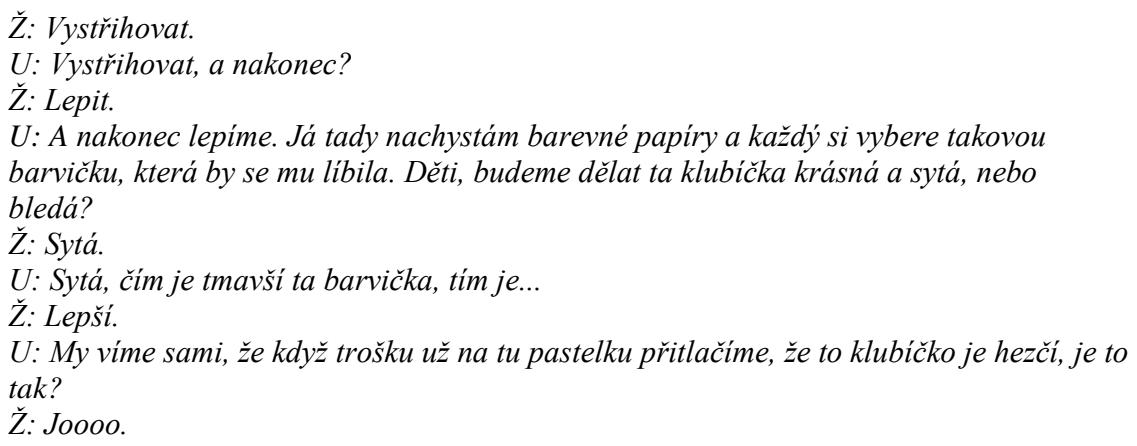

I v př́padech, kdy je hodnocení žáků víceslovné, jsou věty poměrně jednoduché, často jsou naduživána zájmena (např. U: Jakou chybu má Janička? Ž-D: Že to má takhle a ne takhle.).

Z hlediska citového zabarvení jsme identifikovali jak pozitivní, tak negativní hodnotící výroky. Z hlediska zpětné vazby se u žáků vyskytovalo nejčastěji hodnocení bez zdůvodnění, následovalo hodnocení se zdůvodněním (např. U: Proč to není správně, kdo to ví? Ž-D: Protože tam začínaji být mezery.) Hodnotící výroky obsahující návrhy k překonání nedostatků se u žáků nevyskytovaly vůbec. Dále jsme rozlišovali analytické a holistické pojetí hodnocení, zde můžeme konstatovat, že hodnocení holistické bylo vyslovování žáky dvakrát častěji než hodnocení analytické. Shodně s hodnotícími výroky učitelky převažovalo hodnocení kriteriální, žáci zohledňovali kritéria, která učitelka nastavila na začátku sledovaných vyučovacích hodin.

Z hlediska obsahu hodnocení žáci nejčastěji hodnotili výsledek činnosti ostatních žáků, minimálně byla hodnocena snaha nebo aktivita a dovednosti žáků. Žákovské znalosti a postoje nebyly hodnoceny vůbec. Hodnocení bylo nejčastěji adresováno dívkám, následovaly hodnotící výroky bez určení adresáta - anonymní, dále bylo identifikováno hodnocení skupiny žáků a hodnocení chlapců. Sebehodnocení a hodnocení učitele se vyskytlo pouze ve dvou hodnotících situacích.

Z hlediska užití jazyka v žákovském hodnocení převažovaly výroky s použitím posuzujícího jazyka (např. U: Kdo mi řekne něco k této kočičce? Ž: Nejkrásnější.). Popisný jazyk je žáky často užíván v replikách hodnotících výroků učitelky.

\section{Ukázka 2:}

U: Honzík mě, dèti, neposlouchá, podivejte se a řekněte, jaké dèlá chyby? Podivejte se k tomu zobáčku.

D: Nechává tam ústřižky papiru.

U: Ano, vủbec nejel po té černé čárce, neposunuje těmi nůžkami. Honzi, už jsem ti to ukazovala před měsicem. Dívej se, zakousneš se těma nưžkama, posunuješ se po té ćárce a otáčís tím papirkem. Vidiš to? Ty jsi to tady kolem té hlavičky neodstřihl. To tam prece vůbec nemũže být, že. Ty už mášs nastř̌ižený zobáček, ty jsi ji ho málem ustřihnul. Počkej, já se podivám, jestli nemám lepši nůžky. A kdo má hotovo stříhá už druhou. Honzi, zkusíme tyto nůžky. Ony jsou podobné, ale zkusime, jestli se nebude střihat líp tady těma delšíma. A posunuj, divej se. Tady posunuj po černé ćáre. Tak Honzíku, je to lepši nebo stejné? Ž-C: Stejné. 
U: Tak si můžě̌s vybrat, které nưžky chceš. Karolínka taky nestřihá přesně. Jakou chybu má Karolinka? Evi, podivej se a řekni.

Ž-D: Nestříhá to po čárce.

U: Ano, nestříhá to po černé ćárce.

Z hlediska participace žáků nejčastěji vynáší hodnotící výroky žáci hromadně, následuje hodnocení dívek a hodnocení chlapců. Většina hodnocení žáků vznikla jako reakce na výzvu nebo dotazování učitelky. Hodnocení bez vyzvání bylo identifikováno pouze $\mathrm{v}$ jednom př́padě.

\section{Shrnutí a diskuse}

Vzhledem $\mathrm{k}$ tomu, že je hlavním nositelem pedagogického dění v podobě hodnocení ve všech sledovaných kategoriích učitelka, hodnotící výroky žáků byly př́imo závislé na jejích výzvách. Žáci byli podněcování $\mathrm{k}$ hodnocení $\mathrm{v}$ různých podobách $\mathrm{i}$ oblastech, vyjadřovali své hodnotící soudy jak verbálně, tak neverbálně. Slovní hodnocení formulované žáky se vyskytovalo jak v podobě dokončování vět učitelky, tak jako samostatné hodnotící výroky se zdůvodněním. Hodnotící výroky obsahující návrhy k překonání nedostatků se u žáků nevyskytovaly vůbec. Velmi často byly identifikovány jednoslovné nebo velmi stručné odpovědi na dotazy učitelky směřující $\mathrm{k}$ hodnocení průběhu práce žáka nebo $\mathrm{k}$ jeho výsledku. Absenci složitějších hodnotících výroků je možné zdůvodnit vývojovými specifiky žáků mladšího školního věku, nedostatkem zkušeností s hodnocením práce ostatních a možnými psychickými překážkami pojícími se slovním projevem před třídou.

Z hlediska procesu učení byla identifikována převaha sumativně orientovaných hodnotících výroků žáka. Jak uvádí V. Laufková, (2016), formativní hodnocení je žáky i učiteli často spojováno se spravedlivostí, logicky je tedy žáky i lépe přijímáno. $Z$ toho důvodu jsme předpokládali postupné zvýšení frekvence výskytu formativního hodnocení i ze strany žáků, a to i přsesto, že je formativní hodnocení časově náročnější a jeho realizace může být ve výuce „na úkor učení“. (Heritage, 2007) Tento předpoklad se nám však nepotvrdil.

Žákovské hodnocení bylo realizováno nejčastěji jako hodnocení dle učitelkou předem stanovených kritérí. Ta byla prezentována jak na začátku sledovaných hodin, tak $\mathrm{v}$ jejich průběhu. Žáci se na tvorbě kritérií nepodíleli vůbec. Z hlediska obsahu hodnocení žáci nejčastěji hodnotili výsledek práce žáka, kde měli za úkol identifikovat chyby a ocenit pozitiva. Mimo to hodnotili i snahu a nasazení spolužáků při vlastní práci nebo práci ve skupině. Znalosti ani postoje žáci nehodnotili v žádné ze sledovaných vyučovacích hodin. Žáci vyslovovali hodnotící výroky samostatně i hromadně, vždy na základě výzvy učitelky.

Navozování sebehodnotících aktivit žáka v pozorovaných hodinách probíhalo prostřednictvím pro žáky přirozeného učení nápodobou od učitele, který provádí systematické hodnocení s argumentací. Učitelovo hodnocení by však mělo splňovat určité podmínky, kromě požadavku na srozumitelnost, přiměřenost, pozitivní zaměření, orientaci na individuální výkon žáka a jeho pokroky, je to také uživání popisného jazyka a celková snaha o formativní hodnocení. Dle výsledkủ výzkumu realizovaného mezi žáky primární školy žáci preferují zhodnocení výkonu a poskytnutí zpětné vazby právě prostřednictvím 
popisného jazyka (Coview, 2005). Ze záznamu sledovaných hodin je patrné, že žáci opakují typy a formulace hodnotících výrokủ učitelky. Žáci, shodně s učitelkou, používají posuzující a popisný jazyk spiše nahodile.

Následovalo hodnocení žáků navzájem dle předem stanovených kritérií, včetně zdůvodnění hodnotících výroků. Kritéria byla ve sledovaných vyučovacích hodinách učitelkou vymezována před započetím vlastní činnosti žáků společně s demonstrací výsledného výrobku a následně $\mathrm{v}$ průběhu hodin opakována (nejčastěji při dílčím formativním hodnocení práce žáků). Hodnotící kritéria byla učitelkou prezentována jako definitivní a závazná. Mezi hodnotící kritéria učitelka řadila jak primární hodnotící kritéria, kam začleňovala úroveň osvojení praktických dovedností, pracovní zručnost žáka, kvalitu vypracování (např. syté barvy jsou hezčí, než bledé; užši spirály jsou lepší, než široké; aj.), tak sekundární. Na tvorbě kritérií se žáci nepodíleli, nicméně byli zapojeni do jejich vyvození návodnými otázkami.

Při nácviku hodnotících aktivit je $\mathrm{v}$ analyzovaných hodinách patrná snaha postupu od jednoduššího ke složitějšímu, kdy žák nejdříve vyhledával chybu a následně posuzoval její závažnost. Až poté hodnotil celý výrobek i průběh jeho výroby souhrnněji. V průběhu sledovaných hodin byli žáci vyzývání jak k vyhledávání chyb, tak ke komplexnějšímu posouzení výrobku nebo jeho dílčí části.

\section{Závěr}

Vzdělávání na 1. stupni základní školy je založeno na poznávání, respektování a rozvíjení individuálních potřeb každého žáka a má pomoci utvářet a postupně rozvíjet klíčové kompetence stanovené v RVP ZV. Jedním z důležitých nástrojů rozvoje kompetencí žáků je hodnocení výsledků vzdělávání, jehož nedílnou součástí je i rozvoj sebehodnocení žáka. V edukační realitě se však můžeme setkat se situacemi, kdy tato forma hodnocení stagnuje. ${ }^{7}$

Technická výchova vzhledem ke svému interdisciplinárnímu charakteru a úzkému sepětí teorie s praxí, vytvář́ vhodný prostor $\mathrm{k}$ tomu, aby si mohl žák osvojovat potřebné znalosti a rozvíjet sebehodnotící dovednosti. Př́nos technické výchovy v oblasti rozvoje sebehodnocení je možné spatřovat především v různorodém charakteru činností v technické výchově, který umožňuje při hodnocení uplatňovat širokou škálu kritérií zprostředkující žákovi proces hodnocení z více úhlů pohledu.

$\mathrm{V}$ pedagogické praxi je možné zaznamenat uplatňování rozdílného př́stupu hodnocení $\mathrm{v}$ předmětech $\mathrm{s}$ převahou praktických činností, s převahou výchovného působení a $\mathrm{v}$ předmětech $\mathrm{s}$ převahou kognitivního působení. Vzhledem $\mathrm{k}$ tomu, že veškerou vzdělávací i hodnotící činnost řídí učitelka, ta jediná poskytovala prostor $\mathrm{k}$ vyjadřování žákovských názorů i postojů. Vzhledem $\mathrm{k}$ tomu, že žáci v raném mladším školním věku bezvýhradně akceptují názory a tvrzení učitelky, je její „moc“8 při hodnocení takřka neomezená. Žáci mladšího školního věku však z podstaty nejsou schopni adekvátně vyjadřovat vlastní hodnotící soudy, proto je úkolem učitelky zapojovat žáky do hodnotících činností tak, aby si postupně osvojovali škálu hodnotících výroků v různé podobě a přirozeně tak rozvíjeli vlastní dovednost hodnotit.

\footnotetext{
${ }^{7}$ Více např. Rakoušová (2008).

${ }^{8}$ Problematikou moci ve vyučování se zabývá např. K. Šed'ová (2015).
} 
Výběrem výzkumného vzorku jsme se snažili zachytit a popsat specifické faktory ovlivňující volbu hodnotících strategií učitele v prvním ročníku primární školy jako podklad ke zmapování hodnotících procesů na primární škole. Ve sledovaném ročníku působila jako tř́íní učitelka zkušená pedagožka s dlouholetou praxí, u které představoval nejvýznamnější faktor ovlivňující volbu hodnotících strategií její dosavadní pedagogické zkušenosti. V souvislosti s tímto faktem se tedy nabízí několik otázek, které by mohly být předmětem dalšího zkoumání. Např. Které faktory jsou rozhodujicí při formováni hodnotícich strategii začinajicího učitele? Je možné vytvořit typologii učitelu dle uplatňovaných hodnoticich strategii v technické výchově? Jak se liší uplatňované hodnotící strategie učitelỉ v závislosti na délce jejich praxe? Jakou roli sehrává pregraduálni príprava budoucích učiteli̊? Funguje ŠVP jako zásadni dokument, kterýtvoři rámec budoucich hodnoticich strategii začinajicího učitele? Jsou tato závazná pravidla dostatečně rozpracována? A mnohé další.

Přestože sebehodnocení žáků $\mathrm{v} 1$. ročníku základní školy $\mathrm{z}$ vývojového hlediska nemůže odpovídat skutečné realitě, je třeba systematicky a cíleně rozvíjet myšlení žáků a současně korigovat jejich názory př́mou zkušeností $\mathrm{s}$ hodnocením. Ta může být zprostředkována prostřednictvím:

- uplatňováním různých typů hodnocení učitele s důrazem na jejich formativní charakter,

- učení nápodobou slovního hodnocení učitele nebo metodou dokončování vět,

- vyhledáváním odchylek při činnosti v porovnání s hodnotícími kritérii,

- společného vyvozování základních hodnotících kritérií,

- hodnocení dílčích úkonů práce ostatních žáků,

- stručného zdůvodněním hodnocení a formulace návrhů ke změnám,

- pokusů o komplexní hodnocení neverbální formou.

\section{Literatura}

Bellack, A. A., et al. (1966). The Language of the Classroom. New York: Teachers College Press.

Cowie, B. (2005). Pupil commentary on assessment for learning. The Curriculum Journal, 16(2), s137-151. ISSN 1469-3704.

Čapek, R. (2015). Moderni didaktika. Praha: Grada.

Částková, P. \& Provázková Stolinská D. (2017). Analýza hodnotících činností v technické výchově na primární škole. In. Journal of Technology and Information Education. 2017, 9(2), s. 88-104. DOI 10.5507/jtie.2017.011.

Ćástková, P. (2017). The personality aspects of the pupil of the primary school influencing the self-assessing processes in the Technical Education. EDULEARN Proceedings 2017. 9th International Conference on Education and New Learning Technologies. pp. 3203-3213. doi: 10.21125/edulearn.2017.0168.

Cástková, P. (2018). Rozvoj sebehodnocení žáka v technické výchově na primární škole. Olomouc. Rigorózní práce. Univerzita Palackého v Olomouci.

Flanders, N. A. (1950). Analyzing teaching behavior. Reading, Mass.: Addison-Wesley Pub. Co.

Hartl, P. \& Hartlová, H. (2000). Psychologický slovnik. Praha: Portál.

Hendl, J. (2005). Kvalitativní výzkum: základni metody a aplikace. Praha: Portál. 
Heritage, M. (2007). Formative Assessment: What Do Teachers Need to Know and Do? Phi Delta Kappan, Vol 89, Issue 2, pp. 140 - 145.DOI: 10.1177/003172170708900210. Honzíková, J. (2016). Kreativní uchopení diagnostických metod v technické výchově. Trendy ve vzdělávání [online]. 9(1), 97-100 [cit. 2017-04-21]. DOI: 10.5507/tvv.2016.013. Dostupné z: http://tvv-journal.upol.cz/pdfs/tvv/2016/01/13.pdf

Kolár̆, Z. \& Šikulová, R. (2009). Hodnoceni žáki̊. 2., dopl. vyd. Praha: Grada.

Koštálová, H., Miková, Š. \& Stang, J. (2012). Školni hodnoceni žákủ a studentů: se zaměrením na slovni hodnoceni. Praha: Portál, 2012.

Kratochvílová, J. (2011). Systém hodnoceni a sebehodnoceni žákio: zkušenosti z České republiky i Evropských škol. Brno: MSD.

Laufková, V. (2016). Formativni hodnoceni. Praha: Pedagogická fakulta. Univerzita Karlova v Praze. Disertační práce. Vedoucí práce PhDr. Karel Starý, Ph.D.

MŠMT. Rámcový vzdělávací program pro základní vzdělávání. (2016). Praha: Výzkumný ústav pedagogický v Praze, Dostupné z: <http://www.vuppraha.cz/wpcontent/uploads/2009/12/RVPZV_2007-07.pdf>.

Pasch, M. Et al. (1998). Od vzdělávacího programu $k$ vyučovaci hodině: jak pracovat s kurikulem. Praha: Portál.

Průcha, J, Walterová, E. \& Mareš, J. (2009). Pedagogický slovník. 6. aktualiz. a rozš. vyd. Praha: Portál.

Průcha, J., Walterová, E. \& Mareš, J. (2009). Pedagogický slovník. Praha: Portál.

Rakoušová, A. (2008). Sebehodnocení žáků. Metodický portál RVP: Inspirace a zkušenosti učiteli̊ [online]. Dostupné z: http://clanky.rvp.cz/clanek/c/Z/1965/sebehodnocenizaku.html/

Skalková, J. (2007) Obecná didaktika: vyučovací proces, učivo a jeho výběr, metody, organizačni formy vyučování. Praha: Grada.

Slavík, J. (1999). Hodnocení v současné škole: východiska a nové metody pro praxi. Praha:

Portál.

Slavík, J. (2009). Hodnocení a klasifikace žáků a studentů. In. PRŮCHA, Jan, et al. Pedagogická encyklopedie. Praha: Portál.

Stake, R. E. (1995). The art of case study research. Thousand Oaks: SAGE Publications. Straková, J. (2008). Rozvijení a hodnoceni kličových kompetenci v české škole. Brno, Disertační práce. Masarykova Univerzita, Pedagogická fakulta. Vedoucí práce Oldřich Šimoník.

Strauss, A. L., J. Corbin. (1999). Základy kvalitativního výzkumu: postupy a techniky metody zakotvené teorie. Brno: Sdružení Podané ruce.

Svatoš, T. (1995). Flandersova metoda interakční analýzy v učitelské přípravě. Pedagogika, 45, (č.1), pp. 64-70.

Šed’ová, K. (2015). Moc v dialogickém vyučování. Pedagogická orientace [online]. 25(1), 32-62 [cit. 2017-08-28]. DOI: 10.5817/PedOr2015-1-32. ISSN 1805-9511. Dostupné z: https://journals.muni.cz/pedor/article/view/2985

Švaříček, R., Šed'ová, K. et al. (2007). Kvalitativní výzkum v pedagogických vědách. Praha: Portál.

Turek, I. (1987). Didaktika technických predmetov. 1. Bratislava: Slovenské pedagogické nakladatelství.

Vágnerová, M. (2010). Psychologie osobnosti. Praha: Karolinum. 